\title{
PROPOFOL AND NITRIC OXIDE IN TNF-ALPHA INDUCED HUMAN ECV3 04 APOPTOSIS
}

Authors: Zhengyuan Xia, MD, $\mathrm{PhD}^{1 ; 2}$, Tao Luo, $\mathrm{MD}^{1}$, Fang Wang, MD ${ }^{1}$, Min Liu, MD ${ }^{1}$, Zhong-yuan Xia, MD ${ }^{1}$ and David M Ansley, MD, FRCPC ${ }^{3}$

Institutions: ${ }^{1}$ Anesthesiology research laboratories, Dept of Anesthesiology, Renmin hospital of Wuhan University; Wuhan, China; ${ }^{2}$ Faculty of Pharmaceuticals, The University of British Columbia, Vancouver, BC, Canada; ${ }^{3}$ Dept of Anesthesiology, University of British Columbia, Vancouver, BC, Canada

INTRODUCTION: Tumor necrosis factor-alpha (TNF) is increased in pathological conditions such as myocardial ischemia-reperfusion and in diabetes, exacerbating cardiovascular complications. Nitric oxide (NO) may play a dual role in TNF-induced vascular endothelial cell apoptosis, ${ }^{1 ; 2}$ a phenomenon accompanied by increased oxidative stress. We investigated whether the concomitant application of propofol (P), an intravenous anesthetic with antioxidant properties, with NO donor L-arginine (LA) could confer protective effects on TNF induced human umbilical vein endothelial cells (HUVECs) apoptosis.

METHODS: Cultured HUVECs (cell line ECV304) were either not treated (control), or treated with TNF-alpha $(40 \mathrm{ng} / \mathrm{mL})$ alone $(\mathrm{T})$ or TNF-alpha in the presence of $50 \mu \mathrm{M}$ propofol $(\mathrm{P}+\mathrm{T})$, $100 \mu \mathrm{M}$ LA (LA+T), $100 \mu \mathrm{M}$ L-NNA (a NO synthase inhibitor) (L-NNA+T), propofol and LA $(\mathrm{P}+\mathrm{LA}+\mathrm{T})$ or propofol and L-NNA $(\mathrm{P}+\mathrm{LNNA}+\mathrm{T})$, respectively, for $24 \mathrm{hr}$. Cell viability was measured by MTT (3-[4,5-dimethylthiazol-2-yl]-2,5-diphenyltetrazolium bromide) assay, a widely used method in assessment of cytotoxicity and cell viability. Results of the MTT assay were compared to another cytotoxicity test, the LDH (lactate dehydrogenate) release assay. Apoptosis in HUVECs was assessed by flow cytometry, and compared to DNA ladder assay. Data were expressed as mean \pm SEM and analyzed with one-way ANOVA with multiple comparisons.

RESULTS: The apoptotic index (AI, the ratio of apoptotic cells) in control was $1.48 \pm 0.46 \%$. TNF increased AI to $34.76 \pm 0.88 \%$ ( $\mathrm{P}<0.01 \mathrm{vs}$ control). This is accompanied by increased release of $\mathrm{LDH}(156.52 \pm 6.48 \mathrm{U} / \mathrm{L}$ in $\mathrm{T}$ vs $35.65 \pm 2.50 \mathrm{U} / \mathrm{L}$ in control, $\mathrm{P}<0.01)$ and increased lipid perioxidation product malondialdehyde (MDA) $(1.03 \pm 0.04 \mathrm{nmol} / \mathrm{mg}$ protein in $\mathrm{T}$ vs $0.69 \pm 0.03$ $\mathrm{nmol} / \mathrm{mg}$ protein in control, $\mathrm{P}<0.01$ ). Propofol attenuated (AI: $27.78 \pm 1.01 \%$ in $\mathrm{P}+\mathrm{T}$ ) while Larginine (AI: $41.1 \pm 1.24 \%$ in $\mathrm{LA}+\mathrm{T}$ ) exacerbated TNF-induced apoptosis ( $\mathrm{P}<0.01 \mathrm{vs}$ T). Propofol plus L-arginine did not have significant effect on TNF-induced apoptosis (AI: $38.86 \pm 1.51 \%$ in $\mathrm{P}+\mathrm{LA}+\mathrm{T}, \mathrm{P}=\mathrm{NS}$ vs $\mathrm{T}$ ). In contrast, propofol plus L-NNA effectively reduced TNF-induced apoptosis (AI: $8.58 \pm 0.75 \%, \mathrm{P}<0.01$ vs $\mathrm{T}$ or $\mathrm{P}+\mathrm{T}$ ), and prevented increases in MDA and LDH release $(\mathrm{P}=\mathrm{NS}, \mathrm{P}+\mathrm{LNNA}+\mathrm{T}$ vs control).

CONCLUSION: NO supplementation may unmask potential protective effects of propofol that attenuates TNF-induced vascular endothelial cell apoptosis.

\section{REFERENCES:}

1.Circ Res. 2003;92:732-40. 2. J Lab Clin Med. 2004;144:148-55. 